\title{
Efektivitas Seduhan Teh Rosella Kering Terhadap Peningkatan Kadar Hemoglobin Pada Ibu Hamil
}

\section{Sagita Darma Sari ${ }^{1}$, Marcatus Soleha ${ }^{2}$, Indah Rahmadaniah ${ }^{3}$ \\ STIKES Abdurahman Palembang ${ }^{1,2,3}$}

\author{
A B S T R A K
}

Informasi Artikel :

Diterima : 28 Oktober 2021

Direvisi : 02 November 2021

Disetujui : 20 Desember 2021

Diterbitkan : 30 Desember 2021

*Korespondensi Penulis : sagitadarmasari98@gmail.com ${ }^{1}$
Berdasarkan data hasil Riset Kesehatan Dasar (RISKESDAS) tahun 2018, prevalensi angka kejadian anemia pada kehamilan di Indonesia sebanyak 48,9\%. Faktor penyebab anemia pada ibu hamil adalah karena kekurangan zat besi dalam tubuh. Salah satu upaya untuk meningkatkan penyerapan zat besi didalam tubuh yaitu dengan cara meningkatkan asupan vitamin C. Rosella (hibiscus sabdariffa) merupakan tanaman herbal dengan kandungan vitamin $\mathrm{C}$ yang tinggi 9 kali lipat dari jeruk citrus dan 10 kali lipat dari buah belimbing. Tujuan dari penelitian ini adalah mengetahui efektivitas seduhan teh rosella kering terhadap peningkatan kadar hemoglobin pada ibu hamil trimester II. Metode penelitian ini menggunakan Quasy Eksperiment dengan pendekatan nonequivalent control-group, Analisa data menggunakan analisis univariat, bivariat menggunakan uji t-test. Sampel dalam penelitian ini adalah ibu hamil trimester II dengan jumlah 20 responden dibagi menjadi 2 kelompok. Kelompok eksperimen diberikan seduhan teh rosella kering dengan dosis $115,2 \mathrm{mg} / \mathrm{kgBB} / \mathrm{hari}$ sedangkan pada kelompok kontrol diberikan tablet $\mathrm{Fe}$ 1x1/hari. Setelah 14 hari, maka akan dilakukan pemeriksaan kadar hemoglobin kembali baik pada kelompok eksperimen maupun pada kelompok kontrol. Hasil uji $t$-test dengan taraf signifikansi $\alpha=0,05$ didapatkan $(p$ value $=0,045)$ pada kelompok eksperimen dan $(p$ value $=0,046)$ pada kelompok kontrol dengan nilai rata-rata terjadi peningkatan kadar hemoglobin pada kelompok eksperimen sebanyak $1.070 \mathrm{gr} / \mathrm{dl}$ sedangkan rata-rata peningkatan kadar hemoglobin pada kelompok kontrol $0.900 \mathrm{gr} / \mathrm{dl}$ sehingga dapat disimpulkan adanya efektivitas seduhan teh rosella kering terhadap peningkatan kadar hemoglobin pada ibu hamil trimester II.

Kata Kunci : Seduhan teh rosella kering, Anemia, Kadar hemoglobin

\section{ABSTRACT}

Based on data from the basic health research (RISKESDAS) in 2018, prevalence of anemia in pregnancy in Indonesia as 48,9\%. The factory of anemia causes pregnancy women were minus of iron substance in their body. The one of efforts to increase the absorption in their body were increasing the vitamin C. Rosella (hibiscus sabdariffa) is an plant with vitamin $C$ of the highest 9 times the citrus and 10 times starfruit. The purposed of this researched determited the effectiveness of steeping dry rosella tea to increase the hemoglobin levels on trimester II of pregnancy 
women. This research method used Quasy Eksperiment with nonequivalent control-group, the datum analysis were univariate analysis, bivariate using t-test. The sample in this research were 20 respondents of trimester II pregnant women, divided into 2 groups. The experiments group was given steeping dry rosella tea with a dose of 115,2 $\mathrm{mg} / \mathrm{kgBB} /$ day while the control group was given $\mathrm{Fe}$ tablets 1x1/day. After 14 days, hemoglobin levels will be examited again in both the experiment group and the control group. The result of $t$-test with a significance level $\alpha=0,05$ got ( $p$ value $=$ $0,045)$ in experiment group and $(p$ value $=0,046)$ in control group with the average value of hemoglobin levels increase in the experiments group by $1.070 \mathrm{gr} / \mathrm{dl}$ while average the increase of hemoglobin levels in control group is $0.900 \mathrm{gr} / \mathrm{dl}$ so the conclusion of this researched there were effectiveness of steeping dry rosella tea to increase the hemoglobin levels on trimester II of pregnancy women.

Keywords: Steeping dry rosella tea, Anemia, Hemoglobin levels

\section{PENDAHULUAN}

Kehamilan adalah suatu masa yang membutuhkan adaptasi baik secara fisiologis dan psikologis. Kebutuhan energi dan zat gizi lainnya meningkat selama kehamilan. Peningkatan energi dan zat gizi tersebut diperlukan untuk pertumbuhan dan perkembangan janin, pertambahan besarnya organ kandungan, serta perubahan komposisi dan metabolisme tubuh ibu sehingga kekurangan zat gizi tertentu yang diperlukan saat hamil dapat menyebabkan janin tidak tumbuh sempurna. Pola makan yang salah pada ibu hamil memberikan dampak terhadap terjadinya gangguan gizi antara lain anemia (Prakas, 2015).

Menurut World Health Organitation (WHO), dalam konfrensi anemia sedunia tahun 2017 lalu, dinyatakan bahwa sekitar $41,8 \%$ ibu hamil di dunia mengalami kondisi anemia dan $60 \%$ kasus anemia pada ibu hamil ini dikarenakan kekurangan zat besi. Berdasarkan hasil Riset Kesehatan Dasar (RISKESDAS) tahun 2018, prevalensi anemia pada kehamilan di Indonesia mengalami kenaikan $11,8 \%$ yaitu $37,1 \%$ tahun 2013 menjadi 48,9\% tahun 2018 dengan 84,6\% terjadi pada ibu hamil usia 15-24 tahun (Kemenkes RI, 2019), sedangkan angka kejadian anemia di Provinsi Sumatera Selatan pada tahun 2018 dengan total kejadian anemia pada ibu hamil sebesar 28,3\% (Dinkes Sumsel, 2019). Di Kota Palembang tahun 2017 prevalensi angka kejadian anemia pada ibu hamil sebesar 4,9\% dan pada tahun 2018 terjadi peningkatan angka kejadian anemia pada ibu hamil yaitu mencapai 6,2\% (Dinkes Palembang, 2019).

Anemia kehamilan disebut "potential danger to mother and child" (potensial membahayakan ibu dan anak). Ibu hamil dinyatakan anemia jika hemoglobin dibawah 11 gr\%. Dampak anemia pada kehamilan dapat terjadi abortus, persalinan prematuritas, hambatan tumbuh kembang janin dalam rahim, mudah terjadi infeksi, perdarahan antepartum, ketuban pecah dini (KPD), saat persalinan dapat mengakibatkan gangguan his, kala pertama dapat berlangsung lama, dan terjadi partus terlantar, dan pada kala nifas terjadi subinvolusi uteri menimbulkan perdarahan post partum, memudahkan infeksi puerperium, dan pengeluaran ASI berkurang (Aryanti Dkk, 2013).

Penyebab anemia pada ibu hamil adalah kekurangan zat besi dalam tubuh.Anemia defisiensi zat besi merupakan anemia yang disebabkan oleh kurangnya zat besi, asam folat dan vitamin B12 di karenakan asupan yang tidak adekuat atau ketersediaan zat besi yang rendah. Anemia dapat juga terjadi karena konsumsi zat besi dan vitamin $\mathrm{C}$ yang 
rendah. Hal ini berkaitan dengan pola konsumsi makanan masyarakat Indonesia yang masih didominasi oleh pangan nabati, sedangkan pangan hewani jarang dikonsumsi. Faktor penghambat penyerapan zat besi dipengaruhi oleh zat yang kebanyakan ditemukan dalam makanan nabati. Inhibitor terkuat adalah senyawa polifenol seperti tanin. Tanin merupakan polifenol yang terdapat di dalam teh dan kopi (Susiloningtyas, 2017).

Tanin adalah salah satu faktor penghambat penyerapan zat besi yang akan mengikat zat besi sebelum diserap oleh mukosa usus menjadi zat yang tidak dapat larut, sehingga akan mengurangi penyerapannya. Dengan berkurangnya penyerapan zat besi, karena faktor penghambat tersebut, maka jumlah feritin juga akan berkurang yang berdampak pada menurunnya jumlah zat besi yang akan digunakan untuk sintesa hemoglobin dan mengganti hemoglobin yang rusak. Hal ini merupakan salah satu faktor penyebab rendahnya kadar hemoglobin dalam darah (Riswanda, 2017).

Salah satu upaya untuk mencegah anemia yaitu dengan meningkatkan kadar hemoglobin dalam darah, yakni dengan meningkatkan penyerapan zat besi $(\mathrm{Fe})$ dalam tubuh, dengan cara meningkatkan asupan vitamin $\mathrm{C}$. Zat besi nonheme yang rendah absorbsinya dapat ditingkatkan apabila adanya peningkatan asupan vitamin $\mathrm{C}$ dan faktor-faktor lain yang mempermudah absorbsi seperti daging, ikan, dan ayam (Adriani dan Merryana, 2012).

Bunga rosella (Hibiscus Sabdarifa L.) merupakan tanaman herbal tradisional yang memiliki banyak khasiat dalam kesehatan. Tanaman rosela memiliki manfaat yang sangat besar dalam menjaga kesehatan tubuh.Rosella mengandung kalsium, vitamin C, D, B1, B2, magnesium, omega-3, betakaroten, dan 18 asam amino esensial untuk tubuh, diantaranya lysine dan agrine. Kandungan vitamin $\mathrm{C}$ yang ada pada bunga rosela 3 kali lipat dari anggur hitam, 9 kali lipat dari jeruk citrus dan 10 kali lipat dari buah belimbing (Kholis, 2011).

Berdasarkan hasil penelitian yang dilakukan oleh Suwarni tahun 2013 menunjukkan perbedaan kadar hemoglobin sebelum dan sesudah dilakukannya intervensi.
Pada kelompok yang diberikan tablet $\mathrm{Fe}$ dan vitamin $\mathrm{C}$ menunjukkan peningkatan rata-rata sebesar 1,54 gr/dL, dan kelompok yang diberikan Fe saja menunjukkan peningkatan rata-rata sebesar $0,82 \mathrm{gr} / \mathrm{dL}$. Hal tersebut menunjukkan bahwa pemberian tablet $\mathrm{Fe}$ dengan vitamin $\mathrm{C}$ secara bersamaan mampu memperbaiki penyerapan dari besi, dan menyebabkan peningkatan kadar hemoglobin lebih tinggi dibandingkan tanpa vitamin $\mathrm{C}$. Hasil penelitian menunjukkan perbedaan kadar hemoglobin sebelum dan sesudah dilakukannya intervensi. Pada kelompok yang diberikan tablet $\mathrm{Fe}$ dan vitamin $\mathrm{C}$ menunjukkan peningkatan rata-rata sebesar 1,54 gr/dL, dan kelompok yang diberikan Fe saja menunjukkan peningkatan rata-rata sebesar $0,82 \mathrm{gr} / \mathrm{dL}$. Hal tersebut menunjukkan bahwa pemberian tablet $\mathrm{Fe}$ dengan vitamin $\mathrm{C}$ secara bersamaan mampu memperbaiki penyerapan dari besi, dan menyebabkan peningkatan kadar hemoglobin lebih tinggi dibandingkan tanpa vitamin C (Suwarni, 2013).

Penelitian lain juga dilakukan oleh Nisa, Soejoenoes dan Wahyuni pada tahun 2017, yang menunjukkan rerata peningkatan kadar hemoglobin dalam kelompok kontrol adalah $0,61 \mathrm{gr} / \mathrm{dL}$ dan pada kelompok eksperimen adalah $1,08 \mathrm{gr} / \mathrm{dL}$ dengan t-test diperoleh $\mathrm{p}$ value $0,00(<0,05)$ dengan perbedaan rata-rata $0,47 \mathrm{gr} / \mathrm{dL}$, yang menunjukkan bahwa ada perbedaan yang signifikan dari rata-rata tingkat hemoglobin antara kelompok kontrol dan kelompok perlakuan. Penelitian yang sama telah dilakukan oleh Munowaroh (2009) yang mengungkapkan bahwa ekstrak rosella memiliki efek yang signifikan terhadap peningkatan jumlah eritrosit dan kadar hemoglobin pada tikus putih anemia.

\section{METODE PENELITIAN}

Desain penelitian menggunakan Quasi Experiment dan bersifak Non Equivalent Control Group. Penelitian ini menggunakan dua kelompok, satu kelompok yang diberikan perlakuan seduhan teh rosella kering dan satu kelompok sebagai kontrol yang hanya diberikan tablet $\mathrm{Fe}$ saja. Hal ini dilakukan untuk melihat apakah setelah diberikan perlakuan kadar hemoglobin ibu hamil trimester II tersebut mengalami peningkatan dan yang tidak diberi perlakuan mengalami 
perubahan atau tidak sehingga hal tersebut bisa menjadi acuan untuk melihat efektivitas seduhan teh rosella kering terhadap peningkatan kadar hemoglobin pada ibu hamil trimester II di BPM Sagita Darma Sari Palembang tahun 2020.

Populasi dalam penelitian ini adalah seluruh ibu hamil trimester II yang datang ke BPM Sagita Darma Sari Palembang pada saat penelitian sedang berlangsung sesuai dengan kriteria inklusi yang telah ditetapkan. Sampel yang didapat pada penelitian ini yaitu 20 orang yang kemudian dibagi menjadi dua kelompok, 10 orang pada kelompok perlakuan dan 10 orang pada kelompok kontrol. Tehnik pengambilan sampel menggunakan metode Purposive Sampling.

Sebelum penelitian dilaksanakan, seluruh responden diukur kadar $\mathrm{Hb}$ nya terlebih dahulu dan kemudian dicatat dilembar observasi. Secara acak responden akan dimasukkan kedalam kelompok penelitian yang berbeda. Kelompok perlakuan diberikan seduhan teh rosella kering dengan dosis 115,2 $\mathrm{mg} / \mathrm{kgBB} /$ hari selama 14 hari, sedangkan pada kelompok kontrol hanya diberikan tablet Fe saja dengan dosis $60 \mathrm{mg} /$ hari selama 14 hari. Setelah 14 hari kadar $\mathrm{Hb}$ dari masing masing responden diukur dan dicatat kembali pada lembar observasi. Selama 14 hari penelitian , masing - masing responden juga diberikan lembar checklist yang bertujuan untuk mengetahui kepatuhan ibu dalam mengkonsumsi tablet Fe dan rosella kering.

Tempat penelitian ini dilakukan di BPM Sagita Darma Sari Palembang, penelitian ini dilakukan pada bulan April - Mei tahun 2020. Penggumpulan data dengan menggunakan data primer dan menggunakan lembar checklist dan lembar observasi. Analisa data menggunakan uji Paired t-test dan uji normalitas data dengan statistic one sample kolmogrov smirnov test.

\section{HASIL PENELITIAN}

Pelaksanaan penelitian dilakukan pada kelompok perlakuan dan kelompok kontrol selama 14 hari. Hasil penelitian terdapat pada tabel dibawah ini:

\section{Tabel 1. Distribusi frekuensi peningkatan kadar hemoglobin konsumsi seduhan teh rosella kering}

\begin{tabular}{ccc}
\hline $\begin{array}{c}\text { Kadar } \\
\text { Hemoglobin }\end{array}$ & Frekuensi & $\begin{array}{c}\text { Persentase } \\
(\mathbf{\%})\end{array}$ \\
\hline Meningkat & 7 & $70,0 \%$ \\
Tidak & 3 & $30,0 \%$ \\
\hline Total & 10 & $100,0 \%$ \\
\hline
\end{tabular}

Kadar hemoglobin dari 10 responden ibu hamil trimester II yang diberikan seduhan teh rosella kering terdapat peningkatan kadar hemoglobin sebanyak 7 orang responden $(70 \%)$ dan 3 orang responden $(30 \%)$ tidak mengalami peningkatan kadar hemoglobin.

Tabel 2. Distribusi frekuensi peningkatan kadar hemoglobin konsumsi tablet Fe (Kelompok kontrol)

\begin{tabular}{ccc}
\hline $\begin{array}{c}\text { Kadar } \\
\text { Hemoglobin }\end{array}$ & Frekuensi & $\begin{array}{c}\text { Persentase } \\
(\mathbf{\%})\end{array}$ \\
\hline Meningkat & 8 & $80,0 \%$ \\
Tidak & 2 & $70,0 \%$ \\
\hline Total & 10 & $100,0 \%$ \\
\hline
\end{tabular}

Kadar hemoglobin dari 10 responden ibu hamil trimester II yang mengonsumsi tablet Fe terdapat peningkatan kadar hemoglobin sebanyak 8 orang responden $(80 \%)$ dan 2 orang responden $(20 \%)$ tidak mengalami peningkatan kadar hemoglobin.

Tabel 3.Kadar hemoglobin sebelum dan sesudah intervensi pada kelompok perlakuan dan kontrol

\begin{tabular}{ccccc}
\hline \multirow{2}{*}{$\begin{array}{c}\text { Kadar } \\
\text { Hemoglob } \\
\text { in }\end{array}$} & \multicolumn{2}{c}{$\begin{array}{c}\text { Kelompok } \\
\text { perlakuan }\end{array}$} & \multicolumn{2}{c}{$\begin{array}{c}\text { Kelompok } \\
\text { kontrol }\end{array}$} \\
\cline { 2 - 5 } & $\begin{array}{c}\text { Sebelu } \\
\text { m }\end{array}$ & $\begin{array}{c}\text { Sesuda } \\
\text { h }\end{array}$ & $\begin{array}{c}\text { Sebelu } \\
\text { m }\end{array}$ & $\begin{array}{c}\text { sesuda } \\
\text { h }\end{array}$ \\
\hline $\begin{array}{c}\text { Rata-rata } \\
\text { Mini- }\end{array}$ & 10,84 & 11,91 & 10,79 & 11,69 \\
mum & 9,1 & 9,9 & 7,5 & 9,7 \\
$\begin{array}{c}\text { Maksi- } \\
\text { mum }\end{array}$ & 12,4 & 14,2 & 13,3 & 14 \\
\hline
\end{tabular}

Tabel 3 menunjukkan bahwa rata-rata kadar hemoglobin pada kelompok perlakuan sebelum diberikan intervensi seduhan teh 
rosella kering adalah $10.84 \mathrm{gr} / \mathrm{dl}$ dengan kadar hemoglobin terendah $9.1 \mathrm{gr} / \mathrm{dl}$ dan kadar hemoglobin tertinggi $12.4 \mathrm{gr} / \mathrm{dl}$, sedangkan rerata kadar hemoglobin setelah diberikan intervensi seduhan teh rosella yaitu 11.91 gr/dl dengan kadar hemoglobin terendah 9.9 gr/dl dan kadar hemoglobin tertinggi 14.2 gr/dl. Pada kelompok kontrol rata-rata kadar hemoglobin sebelum diberikan intervensi tablet $\mathrm{Fe}$ yaitu $10.79 \mathrm{gr} / \mathrm{dl}$ dan kadar hemoglobin terendah $7.5 \mathrm{gr} / \mathrm{dl}$ dan tertinggi $13.3 \mathrm{gr} / \mathrm{dl}$, sedangkan rerata kadar hemoglobin setelah diberikan intervensi tablet Fe yaitu $11.69 \mathrm{gr} / \mathrm{dl}$ dengan kadar hemoglobin terendah $9.7 \mathrm{gr} / \mathrm{dl}$ dan tertinggi $14.0 \mathrm{gr} / \mathrm{dl}$. Rata-rata masing-masing kelompok mengalami peningkatan kadar $\mathrm{Hb}$, akan tetapi pada kelompok responden yang diberikan perlakuan seduhan teh rosella kering mengalami peningkatan kadar $\mathrm{Hb}$ yang lebih tinggi dibandingkan dengan kelompok responden yang tidak diberikan perlakuan atau hanya sebagai kelompok kontrol dengan nilai rata-rata terjadi peningkatan pada kelompok perlakuan sebanyak 1.070 gr/dl dan pada kelompok kontrol terjadi peningkatan rata-rata hanya $0.900 \mathrm{gr} / \mathrm{dl}$.

\section{Tabel 4. Perbedaan rata-rata kadar hemoglobin sebelum dan sesudah intervensi pada kelompok perlakuan dan kontrol}

\begin{tabular}{ccccc}
\hline $\begin{array}{c}\text { Kadar } \\
\text { Hemoglobin }\end{array}$ & Mean & SD & $\begin{array}{c}\boldsymbol{p} \\
\text { value }\end{array}$ & $\mathbf{n}$ \\
\hline $\begin{array}{c}\text { Seduhan } \\
\text { Teh }\end{array}$ & $-1,070$ & 1.4538 & 0,045 & 10 \\
$\begin{array}{c}\text { Rosella } \\
\text { pretest }-\end{array}$ & & & & \\
$\begin{array}{c}\text { posttest) } \\
\text { Tablet Fe } \\
\text { (pretest- } \\
\text { posttest) }\end{array}$ & $-0,900$ & 1,2284 & 0,046 & 10 \\
\hline
\end{tabular}

Berdasarkan uji- $t$ berpasangan seperti yang ditunjukkan pada tabel 4 diperoleh $p$ value pada kelompok perlakuan yaitu 0,045 $(<0,05)$ dan pada kelompok kontrol 0,046 $(<0,05)$, yang berarti menunjukkan hasil analisis pada kedua kelompok tersebut samasama memiliki pengaruh yang signifikan terhadap peningkatan kadar hemoglobin pada ibu hamil trimester II. Namun diketahui dari hasil analisa, terjadi peningkatan kadar hemoglobin pada kedua kelompok baik kelompok perlakuan maupun kelompok kontrol. Rerata peningkatan kadar hemoglobin pada kelompok perlakuan yaitu 1,070 gr/dl dan pada kelompok kontrol 0,900 gr/dl. Hal tersebut menunjukkan bahwa kadar hemoglobin pada kelompok perlakuan mengalami peningkatan lebih tinggi dari pada kelompok kontrol. Sehingga dapat disimpulkan bahwa ada pengaruh yang signifikan pemberian seduhan teh rosella kering terhadap peningkatan kadar hemoglobin pada ibu hamil trimester II dengan perbandingan rata-rata antar kelompok 1.070;0.900 gr/dl dengan selisih mean 0.170 gr/dl terjadi peningkatan kadar hemoglobin pada ibu hamil trimester II lebih tinggi pada kelompok perlakuan.

\section{PEMBAHASAN}

Berdasarkan penelitian pada 20 orang responden ibu hamil trimester II, didapatkan hasil dari 10 orang responden pada kelompok perlakuan yang mengonsumsi seduhan teh rosella kering selama 14 hari terjadi peningkatan kadar hemoglobin pada 7 orang responden $(70 \%)$ dan 3 orang responden $(30 \%)$ tidak mengalami peningkatan, sedangkan 10 orang responden pada kelompok kontrol yang mengonsumsi tablet Fe terjadi peningkatan kadar hemoglobin sebanyak 8 orang responden $(80 \%)$ dan 2 orang responden $(20 \%)$ tidak mengalami peningkatan.

Diketahui bahwa dari 10 orang responden ibu hamil trimester II sebelum mengonsumsi seduhan teh rosella kering rata-rata kadar hemoglobin dalam darah $10.840 \mathrm{gr} / \mathrm{dl}$, kemudian setelah mengonsumsi seduhan teh rosella kering selama 14 hari rata-rata kadar hemoglobin meningkat menjadi $11.910 \mathrm{gr} / \mathrm{dl}$ dan pada 10 orang responden ibu hamil trimester II pada kelompok kontrol sebelum mengonsumsi tablet $\mathrm{Fe}$ rata-rata kadar hemoglobin $10.790 \mathrm{gr} / \mathrm{dl}$ dan setelah mengonsumsi tablet Fe kadar hemoglobin meningkat rata-rata menjadi $11.690 \mathrm{gr} / \mathrm{dl}$.

Berdasarkan hasil uji statistic t-test diperoleh $p$ value pada kelompok perlakuan yaitu $0,045(<0,05)$ dan pada kelompok 
kontrol $p$ value $0,046(<0,05)$, yang berarti hasil analisis pada kedua kelompok tersebut sama-sama memiliki pengaruh yang signifikan terhadap peningkatan kadar hemoglobin pada ibu hamil trimester II. Namun diketahui nilai rata-rata kadar hemoglobin pada kelompok yang mengonsumsi teh rosella kering terjadi peningkatan sebanyak $1.070 \mathrm{gr} / \mathrm{dl}$ dan pada kelompok yang mengonsumsi tablet Fe terjadi peningkatan sebanyak $0.900 \mathrm{gr} / \mathrm{dl}$. Terlihat dari masing-masing kelompok, terjadi peningkatan kadar hemoglobin, akan tetapi pada kelompok responden yang mengonsumsi seduhan teh rosella kering mengalami peningkatan kadar hemoglobin lebih tinggi dibandingkan dengan kelompok responden yang mengonsumsi tablet Fe dengan selisih rata-rata $0.170 \mathrm{gr} / \mathrm{dl}$ terjadi peningkatan kadar hemoglobin lebih tinggi pada ibu hamil trimester II yang mengonsumsi seduhan teh rosella kering 115,2 mg/kgBB/hari selama 14 hari.

Terjadinya peningkatan kadar hemoglobin lebih tinggi pada ibu hamil trimester II yang mengonsumsi seduhan teh rosella dipengaruhi oleh kandungan zat besi dan vitamin $\mathrm{C}$ yang tinggi pada rosella sehingga dapat meningkatkan absorpsi besi di dalam tubuh, berbeda dengan tablet Fe yang penyerapannya memerlukan asupan vitamin $\mathrm{C}$ dan akan mengurangi penyerapan kandungan zat besinya jika terdapat senyawa polifenol seperti tanin hadir pada makanan yang dikonsumsi.

Hal ini sesuai dengan teori Adriani dan Merryana (2012), yang menyatakan kandungan vitamin $\mathrm{C}$ yang tinggi pada kelopak bunga rosella dapat meningkatkan absorpsi besi dalam bentuk nonheme hingga empat kali lipat, yaitu dengan merubah feri menjadi fero dalam usus halus sehingga mudah untuk diabsorpsi. Rosella mengandung kalsium, vitamin $\mathrm{C}, \mathrm{D}, \mathrm{B} 1, \mathrm{~B} 2$, magnesium, omega-3, betakaroten, zat besi dan 18 asam amino esensial untuk tubuh, diantaranya lysine dan agrine. Kandungan vitamin $\mathrm{C}$ yang ada pada bunga rosela 3 kali lipat dari anggur hitam, 9 kali lipat dari jeruk citrus dan 10 kali lipat dari buah belimbing (Kholis, 2011).

Dalam penelitian ini dosis teh rosella kering yang diberikan pada 10 orang responden ibu hamil trimester II pada kelompok perlakuan adalah 115,2 $\mathrm{mg} / \mathrm{kgBB} /$ hari selama 14 hari. Setiap 100 gram kelopak rosella kering mengandung 260-280 mg vitamin C, vitamin D, B2 dan besi. Selain itu kelopak rosella kering juga mengandung kalsium tinggi (486 mg/100 g) dan asam lemak esensial (Winarti, 2013). Temuan dari penelitian ini menunjukkan bahwa ada pengaruh yang signifikan dari konsumsi seduhan teh rosella kering terhadap peningkatan kadar hemoglobin pada ibu hamil trimester II. Hal ini membuktikan bahwa seduhan teh rosella kering efektif untuk meningkatkan kadar hemoglobin terutama pada wanita hamil dalam penelitian ini.

Hasil penelitian ini didukung oleh penelitian yang dilakukan Nisa, Soejoenoes dan Wahyuni (2017), dalam penelitiannya yang berjudul Effect of Roselle (Hibiscus Safdariffa) on changes in hemoglobin levels in pregnant woman with anemia taking iron supplement jumlah sampel yang digunakan adalah 42 sampel, 21 sampel pada kelompok eksperimen dan 21 sampel pada kelompok kontrol. Dalam penelitian ini dosis ekstrak bunga rosella yang diberikan kepada responden adalah $115,2 \mathrm{mg} / \mathrm{kgBB} /$ hari selama 10 hari. Hasil penelitian dengan uji-t berpasangan diperoleh p-value $0,00(<0,05)$, yang menunjukkan terjadi peningkatan kadar hemoglobin di kedua kelompok eksperimen dan kontrol. Rerata peningkatan hemoglobin pada kelompok kontrol yaitu $0,61 \mathrm{gr} / \mathrm{dl}$ dan pada kelompok perlakuan adalah 1,08 gr/dl. Hal ini menunjukkan ada pengaruh yang signifikan dari konsumsi ekstrak rosella terhadap peningkatan kadar hemoglobin pada ibu hamil.

Penelitian lain yang juga sejalan dengan penelitian ini adalah penelitian yang dilakukan oleh Kristiana dan Pratiwi (2019), Efektivitas Seduhan Teh Rosella Kering Terhadap Peningkatan Kadar Hemoglobin Pada Remaja Putri Di Kota Malang. Jumlah sampel yang didapatkan adalah 30 sampel, 15 sampel pada kelompok eksperimen dan 15 sampel pada kelompok kontrol. Teh rosella dibuat dari 3 kuntum kelopak rosella kering yang diseduh dengan $200 \mathrm{ml}$ air mendidih tutup rapat selama 10 menit. Hasil penelitian menunjukkan kadar Hemoglobin pada 
kelompok perlakuan sebelum dan sesudah perlakuan sebagian besar mengalami kenaikan sebanyak 12 orang (40\%). Dari hasil uji analisa dengan pairedt-test dapatkan bahwa pada kelompok perlakuan nilai P 0,029 $<0,05$ dan pada kelompok kontrol nilai $p$ $0,279>0,05$. Yang artinya ada perbedaan efektivitas seduhan teh rosella kering terhadap peningkatan kadar hemoglobin pada remaja putri sedangkan pada 3 orang responden $(30 \%)$ pada kelompok perlakuan dan 2 orang responden (20\%) pada kelompok kontroltidak terjadi peningkatan kadar hemoglobin. Hal ini dapat disebabkan karena adanya faktor-faktor lain yang tidak dapat dikendalikan oleh peneliti misalnya disebabkan oleh gangguan metabolisme besi dalam tubuh dan pola konsumsi ibu tersebut yang masi didominasi pangan nabati, sedangkan pangan hewani jarang dikonsumsi, faktor inilah yang dapat menyebabkan penghambat penyerapan zat besi.

Hal ini sesuai dengan teori Susiloningtyas (2017), yang menyatakan bahwa faktor penghambat penyerapan zat besi dipengaruhi oleh zat yang kebanyakan ditemukan dalam makanan nabati. Inhibitor terkuat adalah senyawa polifenol seperti tanin. Tanin adalah salah satu faktor penghambat penyerapan zat besi yang akan mengikat zat besi sebelum diserap oleh mukosa usus menjadi zat yang tidak dapat larut, sehingga akan mengurangi penyerapannya. Dengan berkurangnya penyerapan zat besi, hal ini merupakan salah satu faktor penyebab rendahnya kadar hemoglobin dalam darah. Rendahnya kadar hemoglobin menyebabkan suatu kondisi yang disebut anemia. Anemia dalam kehamilan adalah kondisi tubuh dengan kadar hemoglobin dalam darah $11 \mathrm{~g} \%$ pada trimester I dan III atau kadar hemoglobin 10,5 g \% pada trimester II (Aritonang, 2015).

\section{PENUTUP}

\section{Kesimpulan}

1. Rerata kadar hemoglobin pada ibu hamil trimester II sebelum diberikan seduhan teh rosella kering sebanyak 10 responden adalah10.840 gr/dl.

2. Rerata kadar hemoglobin pada ibu hamil trimester II sesudah diberikan seduhan teh rosella kering sebanyak 10 responden adalah11.910 gr/dl.

3. Rerata kadar hemoglobin pada ibu hamil trimester II pada kelompok kontrol sebelum diberikan tablet $\mathrm{Fe}$ sebanyak 10 responden adalah $10.790 \mathrm{gr} / \mathrm{dl}$.

4. Rerata kadar hemoglobin pada ibu hamil trimester II pada kelompok kontrol sesudah diberikan tablet Fe sebanyak 10 responden adalah $11.690 \mathrm{gr} / \mathrm{dl}$.

5. Terdapat perbedaan rerata kadar hemoglobin pada ibu hamil trimester II pada kelompok perlakuan yang diberikan seduhan teh rosella kering yaitu mengalami peningkatan kadar hemoglobin rata-rata $1.070 \mathrm{gr} / \mathrm{dl}$ dan pada kelompok yang diberikan tablet $\mathrm{Fe}$ rata-rata hanya mengalami peningkatan $0.900 \mathrm{gr} / \mathrm{dl}$. Dilihat dari hasil uji statistic t-test didapatkan $p$ value $0.045 \quad(<0.05)$ pada kelompok perlakuan. Maka Ho ditolak dan Ha diterima, adanya efektivitas seduhan teh rosella kering terhadap peningkatan kadar hemoglobin pada ibu hamil.

\section{DAFTAR PUSTAKA}

Adriani dan Merryana,. 2012. Pengantar Gizi Masyarakat. Jakarta: Kencana.

Aritonang, 2015. Kebutuhan Gizi Ibu Hamil. Bogor: IPB Press.

Aryanti, W., Setawati. S., Riyani., Wandiri. R. dan Aryanti.2013. Faktor-faktor yang mempengaruhi kejadian anemia pada ibu hamil. Bandar lampung: PSIK Universitas Malahayati.

Dinas Kesehatan Kota Palembang. 2019. Profil Dinas Kesehatan Kota Palembang Tahun 2019.

Dinas Kesehatan Provinsi Sumatera Selatan. 2019. Rencana Kinerja Tahunan Dikonsentralisasi Dinas Kesehatan Tahun 2019. [online] Tersedi di: http://erenggar.kemkes.go.id

Kementrian Kesehatan RI. 2019. Riset Kesehatan Dasar 2018. [online] Tersedia di: http://www.depkes.go.id [diakses 1 Maret 2020].

Kholis, N. 2011. Bebas Kanker Seumur Hidup Dengan Terapi Herbal. Yogyakarta: Real Books Rosela (Hibiscus Sabdariffa).

Kristiana, A. S. dan Pratiwi, E. D. 2019. Efektivitas Seduhan Teh Rosela Kering Terhadap Peningkatan Kadar Hemoglobin 
Pada Remaja Putri di Kota Malang. Jurnal Wijaya, 6(1), hlm. 6-12.

Munowaroh, S. 2009. Pengaruh Ekstrak Kelopak Rosella (Hibiscus sabdariffa L.) Terhadap Peningkatan Jumlah Eritrosit dan Kadar Hemoglobin Dalam Darah Tikus Putih (Rattus norvegicus) Anemia. [Skripsi]. Malang: Fakultas Sains dan Teknologi Universitas Islam Negeri Maulana Malik Ibrahim.

Nisa, R., Soejoenoes, A. dan Wahyuni, S. 2017. Effect Of Roselle (Hibiscus sabdariffa) On Changes In Hemoglobin Levels In Pregnant Women With Anemia Taking Iron Supplement. Belitung Nursing Journal, 3(6), hlm. 771-777.

Prakash. 2015. Asuhan kebidanan pada kehamilan. Jakarta: Selemba Medika.

Riswanda, J. 2017. Hubungan Asupan Zat Besi dan Inhibitornya Sebagai Prediktor Kadar Hemoglobin Ibu Hamil di Kabupaten Muara Enim. Jurnal Biota, 3 (2), hlm.83-89.

Susiloningtyas, I. 2017. Pemberian Zat Besi (Fe) dalam Kehamilan. Majalah Ilmiah Sultan Agung, 50 (128), hlm. 73-99.

Suwarni, S. 2013. Pengaruh Pemberian Suplemen Besi dan Vitamin C Terhadap Daya Tahan Aerob dan Kadar Hemoglobin. Jurnal Pasca Sarjana:Universitas Sebelas Maret, 1(2), hlm. 1-9.

Winarti, S. 2010. Makanan Fungsional. Yogyakarta: Graha Ilmu. 